\title{
Cytokinin Mediated Increased In Vitro Production of Secondary Metabolites with Special Reference to Solasodine in Solanum erianthum
}

\section{(ㄷ) (i) $(9)$}

\author{
Authors \\ Jeeta Sarkar, Nirmalya Banerjee
}

\begin{abstract}
Affiliation
Cytogenetics and Plant Biotechnology Laboratory, Department of Botany (DST-FIST and UGC-DRS Funded), VisvaBharati (A Central University), Santiniketan, West Bengal, India
\end{abstract}

Key words

Solanum erianthum, Solanaceae, cytokinin, solasodine

received 25.11 .2020

revised 04.03 .2021

accepted 12.04 .2021

\section{Bibliography}

Planta Med Int Open 2021; 8: e62-e68

DOI 10.1055/a-1484-9750

ISSN 2509-9264

(c) 2021. The Author(s).

This is an open access article published by Thieme under the terms of the Creative Commons Attribution-NonDerivative-NonCommercial-License, permitting copying and reproduction so long as the original work is given appropriate credit. Contents may not be used for commercial purposes, or adapted, remixed, transformed or built upon. (https://creativecommons. org/licenses/by-nc-nd/4.0/)

Georg Thieme Verlag KG, Rüdigerstraße 14,

70469 Stuttgart, Germany

\section{Correspondence}

Nirmalya Banerjee, Professor (Retired)

Cytogenetics and Plant Biotechnology Laboratory, Department of Botany (DST-FIST and UGC-DRS Funded), Visva-

Bharati (A Central University)

Santiniketan

West Bengal 731235

India

Tel.: + 919932619010

nirmalya_b@rediffmail.com

Supplementary material is available under http://doi: 10.1055/a-1484-9750.

\section{ABSTRACT}

Steroid alkaloid solasodine is a nitrogen analogue of diosgenin and has great importance in the production of steroidal medicines. Solanum erianthum D. Don (Solanaceae) is a good source of solasodine. The aim of this study was to evaluate the effect of different cytokinins on the production of secondary metabolites, especially solasodine in the in vitro culture of $\mathrm{S}$. erianthum. For solasodine estimation, field-grown plant parts and in vitro tissues were extracted thrice and subjected to high-performance liquid Chromatography. Quantitative analysis of different secondary metabolites showed that the amount was higher in the in vitro regenerated plantlets compared to callus and field-grown plants. The present study critically evaluates the effect of the type of cytokinin used in the culture medium on solasodine accumulation in regenerated plants. The highest solasodine content $\left(46.78 \pm 3.23 \mathrm{mg} \mathrm{g}^{-1}\right)$ was recorded in leaf extracts of the in vitro grown plantlets in the presence of $6-\gamma, \gamma^{-}$ dimethylallylamino purine in the culture medium and the content was 3.8-fold higher compared to the mother plant. 


$\begin{array}{ll}\text { ABBREVIATIONS } \\ \text { 2,4-D } & \text { 2,4-dichlorophenoxyacetic acid } \\ \text { 2-iPA } & 6-\gamma, \gamma \text {-dimethylallylamino purine } \\ \text { ANOVA } & \text { analysis of variance } \\ \text { BA } & \text { N6-benzyladenine } \\ \text { BAP } & \text { 6-benzyl amino purine } \\ \text { CE } & \text { caffeine equivalents } \\ \text { DMRT } & \text { Duncan's multiple range test } \\ \text { DW } & \text { dry weight } \\ \text { GAE } & \text { gallic acid equivalents } \\ \text { IBA } & \text { indole-3-butyric acid } \\ \text { KN } & \text { kinetin } \\ \text { MS } & \text { Murashige and Skoog's medium } \\ \text { PGR } & \text { plant growth regulator } \\ \text { QE } & \text { quercetin equivalents } \\ \text { SE } & \text { standard error } \\ \text { TAE } & \text { tannic acid equivalents } \\ \text { TDZ } & \text { thidiazuron }\end{array}$

\section{Introduction}

Solanum erianthum D. Don of the family Solanaceae is a species of nightshade and native to northern South America and southern North America [1]. It is distributed in tropical and subtropical regions of south India and Andaman [2]. This medicinal species of Solanum is widely used to treat various human disorders [3]. The leaves of S. erianthum have been extensively used for the treatment of headache, vertigo, digestive troubles, haemorrhoids, leucorrhoea, scrofula, and wound healing purposes [4]. It has also been reported to be used as a diuretic and purgative and in the treatment of venereal diseases and leprosy [5]. The leaf extracts of this plant are known to possess antimicrobial and anticancer activities [6]. The experimental plant contains the steroidal alkaloids solanine and solasodine, which have great potential in the drug and pharmaceutical industry [5]. Solasodine can be easily converted to 16-dehydropregnenolone, a key intermediate in steroidal drug synthesis [7], and can be used as an important alternative to diosgenin in the production of steroidal hormones and medicines [8]. In order to meet the demands of the pharmaceutical industry owing to the medicinal value of the species, uncontrolled exploitation of their resources causes depletion of the population from natural habitats [9]. Plant tissue culture techniques in controlled culture conditions provide an alternative to field exploitation of plants for the production of economically important phytochemicals [10]. Micropropagated plants can easily produce commercially desirable secondary metabolites [11]. Micropropagation via different culture pathways has already been established in this medicinal plant [9]. Although very few compounds have been commercially generated in culture, several strategies can be employed in order to further enhance the production of desired secondary metabolites from cultured cells, i. e., fast-growing cell lines with high metabolic activity, genetic engineering, modification of culture media, use of elicitors, etc. [12]. An efficient genetic transfection technique has already been established in S. erianthum with the Agrobacterium rhizogenes A4 strain, and a fast-grown hairy root line has been developed with high secondary metabolite contents [13]. To the best of our knowledge, there has been no report available on comparative analysis of different phytochemical contents in natural and in vitro tissues and propagules in the plant. Keeping the pharmaceutical importance of $S$. erianthum in mind, the present study was undertaken to evaluate various secondary metabolite contents in field and in vitro raised plants.

Metabolite production in vitro can be influenced by the chemical composition of the medium and also by the modulation of culture conditions, of which PGRs act as one of the crucial determinants [14]. The influence of different chemical components as well as PGRs of the culture medium on secondary metabolite production have previously been reported in different plants $[15,16]$. However, no reports are available on the influence of culture modifications on secondary metabolite accumulation in S. erianthum. Thus, this study aimed to investigate the responses of various cytokinins on the accumulation of secondary metabolites of S. erianthum, with special emphasis on solasodine accumulation.

\section{Results}

The secondary metabolite contents were initially estimated from different plant parts, i. e., leaves, unripe fruits, ripe fruits, and roots of in vivo plants of S. erianthum. The highest estimated contents of secondary metabolites were recorded in the in vivo leaf tissues ( $\vee$ Fig. 1 and Table 1S, Supporting Information). Therefore, for further experiments, leaves were used as the control and an in vitro study was conducted using leaf explants.

Quantitative analysis of leaf extracts of the mother plant, in vitro callus tissues, and leaf tissues from in vitro micropropagated plants grown in the presence of different cytokinins (BAP, KN, 2-iPA, TDZ) showed that the contents of various secondary metabolites were significantly higher in the in vitro leaves compared to that of the callus and field tissues. Variations were recorded in the total phytochemical contents of leaves from in vitro micropropagated plants grown in the presence of different cytokinins. Application of 2-iPA significantly increased (1.43-fold) the production of total phenolic compounds, whereas other cytokinins either decreased or had no effect on the phenolic contents ( $\triangleright$ Table 1 ). Flavonoid contents were enhanced in the presence of all the applied cytokinins, while KN showed the highest content (2.2-fold) ( $>$ Table 1). 2-iPA and BAP also caused a significant increase in flavonoids. TDZ showed a remarkably high total tannin content (4.46-fold increase) compared to the control. 2-iPA and KN showed almost similar effects (4fold increase) in tannin production ( $\triangleright$ Table 1 ). This study revealed a potentially high deposition of alkaloids in the in vitro cultures in the presence of various cytokinins. The maximum alkaloid content was recorded in the leaves of in vitro plants in the presence of 2-iPA in the medium.

In another experiment, the in vivo and in vitro plant extracts of S. erianthum were subjected to HPLC analysis for the quantification of the principal alkaloid compound solasodine (Fig. 1S, Supporting Information). The results revealed that the production of solasodine from in vitro leaf tissues was affected to a remarkable extent by cytokinins supplemented to the medium. Quantitative analysis of solasodine showed that its content was significantly higher in 


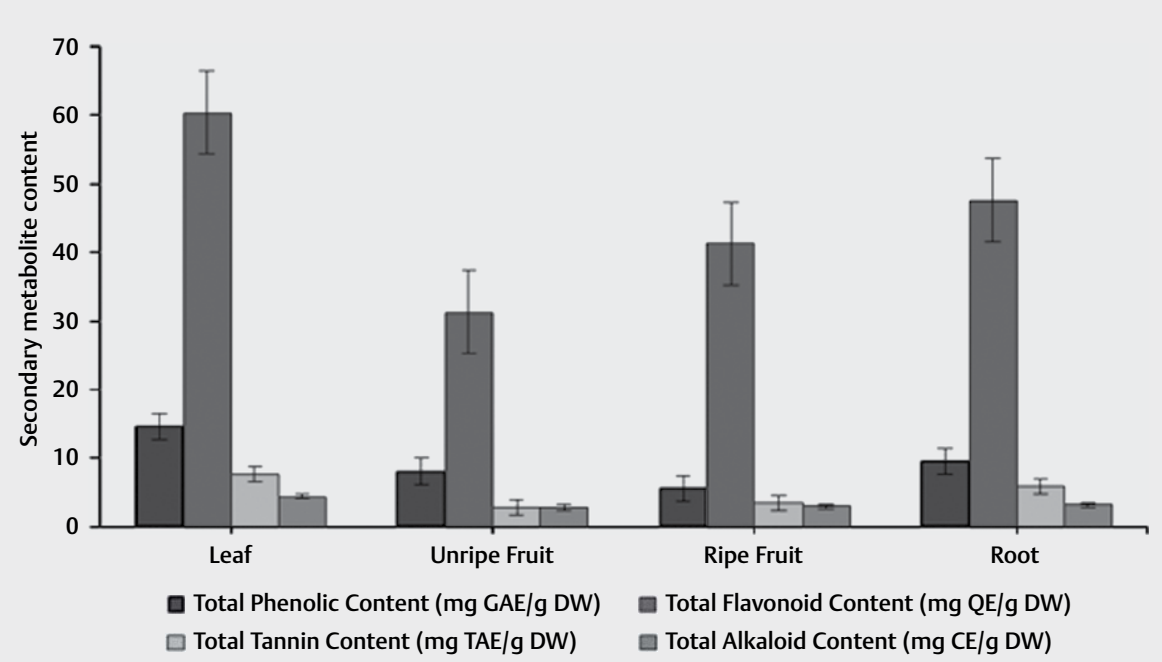

Fig. 1 Comparison of secondary metabolite contents in various parts of S. erianthum field plant.

- Table 1 Comparison of total phytochemical contents between in vivo and in vitro tissues at various cytokinin levels.

\begin{tabular}{|l|c|c|c|c|c|c|}
\hline Phytochemical content & Leaf & Callus & \multicolumn{4}{|c|}{ Leaf from in vitro plant with different treatments } \\
\cline { 4 - 7 } & & & BAP & KN & 2-iPA & TDZ \\
\hline Phenolic (mg GAE/g DW) & $14.58 \pm 0.65 \mathrm{~b}$ & $6.25 \pm 1.53 \mathrm{a}$ & $13.75 \pm 2.70 \mathrm{~b}$ & $14.50 \pm 0.80 \mathrm{~b}$ & $20.92 \pm 4.96 \mathrm{~b}$ & $17.08 \pm 1.69 \mathrm{~b}$ \\
\hline Flavonoid (mg QE/g DW) & $60.33 \pm 2.03 \mathrm{~b}$ & $11.00 \pm 2.31 \mathrm{a}$ & $107.33 \pm 19.55 \mathrm{c}, \mathrm{d}$ & $133.33 \pm 11.67 \mathrm{~d}$ & $109.33 \pm 5.66 \mathrm{c}, \mathrm{d}$ & $80.67 \pm 14.30 \mathrm{~b}, \mathrm{c}$ \\
\hline Tannin (mg TAE/g DW) & $7.57 \pm 0.83 \mathrm{~b}$ & $1.86 \pm 0.83 \mathrm{a}$ & $23.76 \pm 3.44 \mathrm{c}$ & $30.90 \pm 6.92 \mathrm{c}$ & $30.91 \pm 4.97 \mathrm{c}$ & $33.80 \pm 4.54 \mathrm{c}$ \\
\hline Alkaloid (mg CE/g DW) & $4.40 \pm 0.08 \mathrm{~d}$ & $1.59 \pm 0.06 \mathrm{a}$ & $4.49 \pm 0.66 \mathrm{~d}$ & $3.35 \pm 0.16 \mathrm{c}, \mathrm{d}$ & $5.26 \pm 0.87 \mathrm{~d}$ & $2.28 \pm 0.58 \mathrm{~b}, \mathrm{c}$ \\
\hline
\end{tabular}

Experiments were carried out in triplicate and all the data were analysed using ANOVA. The significance of the results was determined statistically using DMRT ( $p \leq 0.05)$. The data are presented as mean values \pm SE. In each row, mean values followed by the same letter are not significantly different at the 0.05 level using DMRT.

- Table 2 Comparison of solasodine content between in vivo leaves and in vitro tissues at various cytokinin levels.

\begin{tabular}{|c|c|c|c|c|c|c|}
\hline \multirow{2}{*}{$\begin{array}{l}\text { Phytochemical } \\
\text { content }\end{array}$} & \multirow[t]{2}{*}{ In vivo leaf } & \multirow[t]{2}{*}{ Callus } & \multicolumn{4}{|c|}{ Leaf from in vitro plant with different treatments } \\
\hline & & & BAP & Kinetin & 2-iPA & TDZ \\
\hline $\begin{array}{l}\text { Solasodine } \\
\text { content }\left(\mathrm{mg} \mathrm{g}^{-1}\right)\end{array}$ & $12.30 \pm 1.56 b$ & $7.26 \pm 2.50 \mathrm{a}$ & $34.60 \pm 6.21 c, d$ & $19.16 \pm 1.11 b, c$ & $46.78 \pm 3.23 d$ & $16.56 \pm 0.62 b$ \\
\hline
\end{tabular}

micropropagated plants compared to field-grown plants and calluses. Interestingly, a 3.8-fold higher solasodine content $(46.78 \pm 3.23 \mathrm{mg} \mathrm{g}-1)$ was recorded in leaf extracts of in vitro plants cultured in 2-iPA-supplemented medium than the mother plants ( Table 2). Similarly, BAP was also found to increase the solasodine content (2.8-fold) in the leaf tissues of the in vitro-generated plants compared to the in vivo tissue. The present study thus indicated that the in vitro-generated shoots had a higher solasodine content compared to that of the callus tissues ( $\mathbf{F i g} . \mathbf{2}$ ). The micropropagated shoots yielded 6 times more solasodine than the callus. All the secondary metabolite contents estimated were statistically significant.

\section{Discussion}

The present study demonstrates that application of certain cytokinins remarkably influences the in vitro production and distribution of secondary metabolites in S. erianthum. Previously, Sarkar et al. [13] estimated a 1.33 -fold increase $\left(16.29 \pm 0.69 \mathrm{mg} \mathrm{g}^{-1}\right)$ in solasodine content in selected hairy root lines of this plant compared to field tissue. The results of the present study revealed even higher solasodine production in the presence of all cytokinins applied and the highest content $\left(46.78 \pm 3.23 \mathrm{mg} \mathrm{g}^{-1}\right)$ was 2.87 -fold higher compared to that of the hairy root.

The effects of PGRs on in vitro production of secondary metabolites are highly variable and depend on the plant species $[17,18]$. Several studies have reported the influence of different PGRs on the in vitro production of secondary metabolites. For example, BAP 


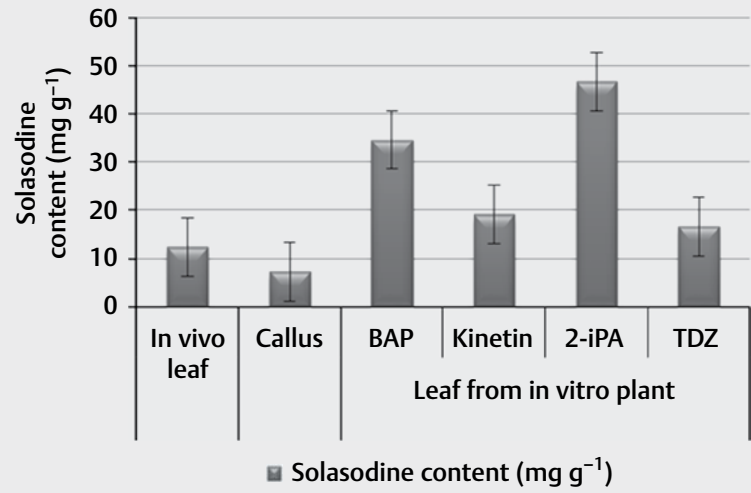

- Fig. 2 Comparison of solasodine content between in vivo leaves and in vitro tissues at various cytokinin levels.

in combination with IBA enhanced the yield of total phenolics and flavonoids in Origanum vulgare and Thymus vulgaris, but decreased in Ocimum basilicum $[19,20]$. In another report, application of BAP increased the total production of essential oils in Mentha piperita [21]. Phenolic content was increased in the culture of Scutellaria columnae when kinetin was added with 2,4-D [22]. Comparative analysis of in vivo and in vitro tissues of Croton floribundus showed dependence of plantlet phytochemical profiles on PGRs [23]. In T. vulgaris, BA was reported to enhance flavonoid production [19]. Cytokinins have been reported to enhance the quantitative production of alkaloids in cultures of Catharanthus roseus [24] and Fagara zanthoxyloides [25,26], anthocyanins in callus of Oxalis linearis [27] and polyphenolic compounds in shoots of Scutellaria alpine [28]. Aremu et al. [29] reported that the presence of 2-iP in the culture medium increased the production of caffeic acid in Merwilla plumbea. BA and other cytokinins were reported to increase phenolic content of in vitro-grown tissues [30, 31]. 2-iPA increased the total flavonoid content in the culture of Piper crassinervium [32]. Experiments performed by Sidkey showed that cytokinins markedly enhanced the accumulation of alkaloids in C. roseus cultures by an increased expression of geranil 10-hydroxlase gene [33]. The results imply that the in vitro production of phytochemical compounds was significantly enhanced by the addition of different cytokinins.

The in vitro production of solasodine could be augmented significantly by the application of PGRs to the culture medium [34]. Auxins have been reported to inhibit alkaloid production in in vitro culture [34]. It was reported to increase glycoalkaloids (i. e., solanine, solamargine, and solasonine) on the leaf culture of Solanum nigrum in the presence of BA [35]. Another report showed $2.4 \mathrm{mg}$ $\mathrm{g}-1$ solasodine content from regenerative callus of $\mathrm{S}$. nigrum in BAcontaining medium [36]. Notably, Bhat et al. estimated solasodine content from different cultured tissues and observed that the content was markedly higher in regenerated shoots compared to callus and field-grown plants [37]. Organogenesis promoted the solasodine production in cultures of Solanum laciniatum in the presence of KN and the enhanced content was $7 \mathrm{mg} \mathrm{g}-1$ in the regenerated shoots [15]. Later, in Solanum trilobatum, the in vitro regenerated plantlets cultured in medium containing $\mathrm{KN}$ and $131.85 \mathrm{mM}$ sucrose accumulated $35.97 \mathrm{mg} \mathrm{g}-1$ solasodine, whereas the mother plants yielded $2.32 \mathrm{mg} \mathrm{g}-1$ [38]. According to Shilpha et al., HPLC analysis of micropropagated plants of S. trilobatum showed $2.47 \pm 0.04 \mathrm{mg} \mathrm{g}-1 \mathrm{DW}$ of solasodine accumulation in the presence of BA in culture medium, while in field-grown plants, the content was $2.38 \pm 0.02 \mathrm{mg} \mathrm{g}-1 \mathrm{DW}$ [39]. On the other hand, MS basal medium without any PGR supplementation was reported to be the best culture conditions for solasodine accumulation in Solanum torvum [34].

Precise control of various factors increases the quality of the metabolite. Manipulation of type and concentration of PGR, size of explants, carbon source, and other medium ingredients affect the rate of secondary metabolite production $[15,40,41]$. With the fact that growth regulators are capable of influencing the growth and development of the plants through their impact on biochemical and physiological processes and also in gene regulation, there are a great number of ways through which these compounds could alter the secondary metabolite production in plants [42]. PGRs are used as efficient elicitors for enhanced production of plant secondary metabolites [43]. According to Staba, the increase in yield of secondary metabolites by PGRs primarily occurs due to an increase in cell division and cell multiplication in culture [44]. Ramawet and Merrilion opined that PGRs do not interact with the intermediary compounds of the biosynthetic pathway of secondary metabolites, but sometimes change cytoplasmatic conditions in metabolite formation [45]. BAP enhanced alkaloid biosynthesis in C. roseus by influencing peroxidase activity [46]. Cytokinins significantly inhibit transporters of macronutrients (nitrate, phosphate, sulphate, ammonium, etc.) and, on the other hand, nitrate normalizes gene expressions involved in secondary metabolite pathways [47]. Again, Cheynier et al. stated that PGRs, especially auxins and cytokinins, influence the production of secondary metabolites by regulating the initial steps of the phenylpropanoid or shikimate pathway [48].

In conclusion, use of leaf explants of $S$. erianthum in the present study provided different somaclonal lines that can be useful for the in vitro production of bioactive compounds. The type of cytokinin has significant influence in the accumulation of secondary metabolites in plantlets of $\mathrm{S}$. erianthum. The in vitro-grown plantlets of this plant also produce increased levels of solasodine, which has a high potential value for steroid drug synthesis. The overall results provided in this article may be useful as an informative source to researchers in the field of natural products.

\section{Materials and Methods}

\section{Plant material}

The seeds of S. erianthum were collected from Hazaribag, Jharkhand, India. Field-grown plants were germinated from the seeds and maintained in the medicinal plant garden of the Department of Botany, Visva-Bharati. The plant specimen (F1/Hzb/2013-26/01/2013) was identified by R. Gogoi, Scientist, Botanical Survey of India, Central National Herbarium, Howrah. The age of the mother plants were about 12-18 months and tissues were collected from more than 3 in vivo plants. In vitro plants were generated via indirect pathways [9] and different somaclonal lines of callus-mediated plantlets were maintai- 
ned in the culture room of the Department of Botany, Visva-Bharati. These somaclonal lines generated in response to different cytokinins were used for secondary metabolite estimation in the present experiment.

\section{Treatments}

Secondary metabolite contents were investigated by culturing shoot tips at half-strength MS medium [49] supplemented with 4 cytokinins, BAP ( $8 \mathrm{mg} \cdot \mathrm{L}-1)$, 2-iPA ( $8 \mathrm{mg} \cdot \mathrm{L}-1), \mathrm{KN}(8 \mathrm{mg} \cdot \mathrm{L}-1)$, and TDZ (1 mg.L - 1). Cultures were maintained at a temperature of $25 \pm 2{ }^{\circ} \mathrm{C}$ and $80-90 \%$ relative humidity under a 12 -h photoperiod of 2500-3000 Ix irradiance in the culture room. The in vitro plant materials were collected 6 weeks after treatment and were utilized for the analysis of secondary metabolite contents.

\section{Total phytochemical study}

The extraction of samples was accomplished as described by Bhattacharyya et al. [50]. Quantitative estimation of total phytochemicals was accomplished using a UV-vis spectrophotometer, U-2900 (Hitachi), at specific wavelengths.

Estimation of total phenolic content was done using the FolinCiocalteu method [51], with small modifications. Of the sample extract, $0.125 \mathrm{~mL}$ was mixed with $1.8 \mathrm{~mL}$ of 10 times diluted FolinCiocalteu reagent. The reaction mixture was kept at $25^{\circ} \mathrm{C}$ for $6 \mathrm{~min}$. Later, $1.2 \mathrm{~mL}$ of $\mathrm{Na} 2 \mathrm{CO} 3$ (20\%) were added to the mixture and incubated for $1.5 \mathrm{~h}$ at room temperature. Finally, phenolic content was determined as mg of GAE per gram of tissue using gallic acid (97.5-102.5\% purity; Sigma-Aldrich) as the standard.

Total flavonoid content was determined using the aluminium chloride colorimetric method at $415 \mathrm{~nm}$ by Chang et al. [52]. Firstly, $0.5 \mathrm{~mL}$ of the tissue extract, $1.5 \mathrm{~mL}$ methanol, $0.1 \mathrm{~mL}$ aluminium chloride (10\%), $0.1 \mathrm{~mL}$ of $1 \mathrm{M}$ sodium acetate, and $2.8 \mathrm{~mL}$ distilled water were mixed by vortexing. The reaction mixture was kept at room temperature for $30 \mathrm{~min}$ followed by a final estimation. The results were noted as $\mathrm{mg}$ of quercetin ( $\geq 95 \%$ purity; Sigma-Aldrich) equivalents (QE) per gram of tissue.

Estimation of total tannin content of the extracts was performed using a modified Folin-Ciocalteu method by Tambe and Bhambar [53]. The sample extract $(0.1 \mathrm{~mL})$ was mixed with $7.5 \mathrm{~mL}$ of distilled water, $0.5 \mathrm{~mL}$ of Folin-Ciocalteu reagent, and $1 \mathrm{~mL}$ of $\mathrm{Na}_{2} \mathrm{CO}_{3}$ (35\%) solution. The volume was made up to $10 \mathrm{~mL}$ by adding glass distilled water. The mixture was shaken well and after incubation at room temperature for $30 \mathrm{~min}$, the absorbance was measured at $725 \mathrm{~nm}$. The calibration curve was prepared for tannic acid (> 95\% purity; Himedia).

Quantification of total alkaloid content was done at $700 \mathrm{~nm}$ by using Dragendorff's alkaloid estimation method [54]. The concentration of the total alkaloid was estimated as mg of CE per gram of tissue using an equation obtained from the caffeine (99\% purity; Sigma-Aldrich) calibration curve.

\section{Quantitative estimation of Solasodine by HPLC}

The solasodine content in selected tissues was quantified using HPLC as per the method of Kittipongpatana et al. [55] with some modifications. The detailed methodology of the HPLC study has already been discussed in Sarkar et al. [13]. Peaks were identified and evaluated by comparing their retention time, UV spectra, and peak area with respect to an authentic solasodine standard ( $\geq 95 \% \mathrm{pu}$ rity; Sigma-Aldrich).

\section{Statistical analysis}

All experiments were carried out in triplicate and the data were analysed using ANOVA. The significance of results was determined statistically using DMRT ( $\mathrm{s} \leq 0.05)$. The data are presented as mean values \pm SE. The data were analysed using SPSS 16.0.0 (IBM Corporation).

\section{Supporting information}

Contents of different secondary metabolites in various parts of the S. erianthum field plant and an HPLC chromatogram of solasodine are available as Supporting Information.

\section{Acknowledgements}

The authors are thankful to the DST-FIST and UGC-SAP (DRS) supported Department of Botany, Visva-Bharati for providing the necessary facilities to carry out this research. Dr. R. Gogoi, (Botanical Survey of India, Central National Herbarium, Howrah) is acknowledged for species identification and Prof. Adinpunya Mitra (Agricultural and Food Engineering Department, IIT, Kharagpur, India) for the HPLC study.

\section{Funding}

The first author is grateful to the University Grants Commission, Govt. of India, for financial support in the form of a UGC-BSR fellowship [No. F.25-1/2013-14(BSR)/7-220/2009(BSR)].

\section{Conflict of Interest:}

The authors declare that they have no conflict of interest.

\section{References}

[1] Battiwala AJ, Shah CS. Bheemachari. Evaluation of Solanum erianthum (D.Don) against certain prostaglandin mediated disorders in animal models. Int J Recent Sci Res 2014; 5: 548-556

[2] Ramya URS, Lakshmidevi N. Short-term toxicity profile of ethanol extract of Solanum erianthum leaf in rats. Int J Pharmacol Clin Sci 2016; 5: 103-108

[3] Alawode T, Lajide L, Owolabi B, Olaleye MT. Phytochemical investigation, in vitro antioxidant and anti-inflammatory evaluation of stem extracts of Solanum erianthum. Int J Herb Med 2018; 6: 01-06

[4] Blomqvist MM, Nguyen T, Padua LS, Bunyapraphatsara N, Lemmens RM. Plant resources of South-East Asia. Med Poisonous. Plants 1999; 12: $453-458$

[5] Mahadev R, Ramakrishnaiah H, Krishna V, Deepalakshmi AP, Kumar NN. Cytotoxic activity of methanolic extracts of Solanum erianthum D. Don. Int J Pharm Pharm Sci 2015; 7: 106-108

[6] Alawode TT, Lajide L, Owolabi B], Olaleye MT, Ogunyemi BT. Antimicrobial studies on leaf and stem extracts of Solanum erianthum. Microbiol Res J Int 2018; 23: 1-6 
[7] Patel K, Singh RB, Patel DK. Medicinal significance, pharmacological activities, and analytical aspects of solasodine: A concise report of current scientific literature. J Acute Dis 2013; 7: 92-98

[8] Ravidran CP, Nandakumar S. Metabolic pathway of solasodine synthesis in Solanum mammosum L. fruits. Int I Innov Res Dev 2015; 4: $150-156$

[9] Sarkar J, Banerjee N. Influence of different cytokinins on micropropagation of an important medicinal plant, Solanum erianthum D. Don, and assessment of the genetic fidelity of the regenerants. In Vitro Cell Dev Biol-Plant 2020; 56: 480-490

[10] Bourgaud F, Gravot A, Milesi S, Gontier E. Production of plant secondary metabolites: A historical perspective. Plant Sci 2001; 161: 839-851

[11] Tisserat SV, Silman R. Influence of modified oxygen and carbon dioxide atmospheres on mint and thyme plant growth, morphogenesis and secondary metabolism in vitro. Plant Cell Rep 2002; 20: 912-916

[12] Verpoorte R, Contin A, Memelink J. Biotechnology for the production of plant secondary metabolites. Phytochem Rev 2002; 1: 13-25

[13] Sarkar ], Misra A, Banerjee N. Genetic transfection, hairy root induction and solasodine accumulation in elicited hairy root clone of Solanum erianthum D. Don. J Biotechnol 2020; 323: 238-245

[14] Radic S, Vujcic V, Glogoski M, Radic-Stojkovic M. Influence of $\mathrm{pH}$ and plant growth regulators on secondary metabolite production and antioxidant activity of Stevia rebaudiana (Bert). Period Boil 2016; 118 : 9-19

[15] Bhatnagar P, Bhatnagar M, Nath AK, Sharma DR. Production of solasodine by Solanum laciniatum using plant tissue culture technique. Indian J Exp Biol 2004; 42: 1020-1023

[16] Zielinska S, Piatczak E, Kalemba D, Matkowski A. Influence of plant growth regulators on volatiles produced by in vitro grown shoots of Agastache rugosa (Fischer \& C.A.Meyer) O. Kuntze. Plant Cell Tiss Organ Cult 2011: 107: 161-167

[17] Khan T, Krupadanam D, Anwar SY. The role of phytohormone on the production of berberine in the calli cultures of an endangered medicinal plant, turmeric (Coscinium fenestratum L.). Afr J Biotechnol 2008; 7: 3244-3246

[18] Paric A, Karalija E. Cakar ]. Growth, secondary metabolites production, antioxidative and antimicrobial activity of mint under the influence of plant growth regulators. Acta Biol Szeged 2017; 61: 189-195

[19] Karalija E, Parić A. The effekt of BA and IBA on the secondary metabolite production by shoot culture of Thymus vulgaris L. Biol Nyssana 2011; 2: 29-35

[20] Karalija E, Neimarlija D, Cakar J, Paric A. Elicitation of biomass and secondary metabolite production, antioxidative and antimicrobial potential of basil and oregano induced by BA and IBA application. Eur J Med Plants 2016; 14: 1-11

[21] Santoro MV, Nievas F, Zygadlo J, Giordano W, Banchio E. Effects of growth regulators on biomass and the production of secondary metabolites in peppermint (Mentha piperita L.) in vitro. Afr J Plant Sci 2013; 4: 49-55

[22] Stojakowska A, Kisiel W. Secondary metabolites from a callus culture of Scutellaria columnae. Fitoterpia 1999; 70: 324-325

[23] Silva BOD, Amaral ACF, Ferreira JLP, Santiago LJM, Louro RP. Micropropagation and in vitro production of secondary metabolites of Croton floribundus Spreng. In Vitro Cell Dev Biol-Plant 2013; 49: 366-372

[24] Decendit A, Liu D, Ouelhazi L, Doireau P, Mérillon JM, Rideau M. Cytokinin-enhanced accumulation of indole alkaloids in Catharanthus roseus cell cultures: the factors affecting the cytokinin response. Plant Cell Reports 1992; 11: 400-403

[25] Couillerot E, Caron C, Audran JC, Jardillier JC, Chenieux JC. Furoquinoline alkaloid accumulation in Fagara zanthoxyloides cell cultures is highly dependent on the presence of exogenous benzylaminopurine. Plant Growth Regul 1996; 19: 203-206
[26] Carpin S, Ouelhazi L, Filali M, Chénieux JC, Rideau M, Hamdi S. The relationship between the accumulation of a $28 \mathrm{kD}$ polypeptide and that of indole alkaloids in Catharanthus roseus cell suspension cultures. J Plant Physiol 1997; 150: 452-457

[27] Meyer HJ, Van Staden J. The in vitro production of an anthocyanin from callus cultures of Oxalis linearis. Plant Cell Tiss Organ Cult 1995; 40: $55-58$

[28] Karolak IG, Kuźma L, Wysokińska H. The effekt of cytokinins on shoot proliferation, secondary metabolite production and antioxidant potential in shoot cultures of Scutellaria alpine. Plant Cell Tiss Organ Cult 2015; 122: 699-708

[29] Aremu AO, Gruz ], Šubrtová M, Szüčová L, Doležal K, Bairu MW. Antioxidant and phenolic acid profiles of tissue cultured and acclimatized Merwilla plúmbea plantlets in relation to the applied cytokinins. J Plant Physiol 2013; 170: 1303-1308

[30] Baskaran P, Moyo M, Van Staden J. In vitro plant regeneration, phenolic compound production and pharmacological activities of Coleonema pulchellum. S Afr J Bot 2014; 90: 74-79

[31] Karalija E, Zeljković SĆ, Tarkowski P, Muratović E, Parić A. The effekt of cytokinins on growth, phenolics, antioxidant and antimicrobial potential in liquid agitated shoot cultures of Knautia sarajevensis. Plant Cell Tiss Organ Cult 2017; 131: 347-357

[32] Ríos-Ríos AM, JVS Silva, JVM Fernandes, Batista DS, Silva TD, Chagas K, MVM Pinheiro, Faria DV, Otoni WC, Fernandes SA. Micropropagation of Piper crassinervium: an improved protocol for faster growth and augmented production of phenolic compounds. Plant Cell Tiss Organ Cult 2019; 37: 495-506

[33] Sidkey BA]. Effekt of plant growth regulators on secondary metabolites accumulation and antioxidant activity of Catharanthus roseus L. Int J Pharm Sci Res 2020; 11: 241-245

[34] Moreira CB, Lima SS, Esquibel MA, Sato A. Solasodine accumulation in regenerated plants of Solanum torvum Sw. Rev Bras Plant Med 2010; 12: 73-79

[35] El-Ashaal HA, Ghanem SA, Melek FR, Kohail MA, Hilal SH. Alkaloid production from regenerated Solanum plants. Fitoterapia 1999; 70: 407-411

[36] Bhat MA, Ahmad S, Aslam J, Mujib A. Mahmooduzzafar. Salinity stress enhanced production of solasodine in Solanum nigrum L. Chem Pharm Bull 2008; 56: 17-21

[37] Bhat MA, Mujib A, Junaid A. Mahmooduzzafar. In vitro regeneration of Solanum nigrum with enhanced solasodine production. Biol Plant 2010; 54: 757-760

[38] Anirudhan K, Nair AS. In vitro production of solasodine from Solanum trilobatum. Biol Plant 2009; 53: 719-722

[39] Shilpha J, Silambarasan T, Largia MJV, Ramesh M. Improved in vitro propagation, solasodine accumulation and assessment of clonal fidelity in regenerants of Solanum trilobatum L. by flow cytometry and SPAR methods. Plant Cell Tiss Organ Cult 2014; 117: 125-129

[40] Rao SR, Ravishankar GA. Plant cell cultures: Chemical factories of secondary metabolites. Biotechnol Adv 2002; 20: 101-153

[41] Xu CM, Ou Y, Zha B, Wang XD, Yuan XF, Wang YC. Syringing production by Saussurea medusa cell cultures in a novel bioreactor. Biol Plant 2008; 52: 377-380

[42] Baskaran P, Ncube B, Van Staden J. In vitro propagation and secondary product production by Merwilla plúmbea (Lindl.) Speta. Plant Growth Regul 2012; 67: 235-245

[43] Jamwal K, Battacharya S, Puri S. Plant growth regulator mediated consequences of secondary metabolites in medicinal plants. J Appl Res Med Aroma 2018; 9: 26-38

[44] Staba E]. Plant Tissue Culture as a Source of Biochemicals. Boca Raton, Florida: CRC Press; 1980 
[45] Ramawet K, Merrilion J. Biotechnology - secondary metabolites. Mohan Primlani for Oxford and YBH, Delhi 1999; 243-247

[46] Zhao J, Zhu W, Qiu H. Effekt of light and plant growth regulators on the biosynthesis of vindoline and other indole alkaloids in Catharanthus roseus callus cultures. Plant Growth Regul 2001; 33: 43-49

[47] Sakakibara H, Takei K, Hirose N. Interactions between nitrogen and cytokinin in the regulation of metabolism and development. Trends Plant Sci 2006; 11: 440-448

[48] Cheynier V, Comte G, Davies KM, Lattanzio V, Martens S. Plant phenolics: recent advances on their biosynthesis, genetics, and ecophysiology. Plant Physiol Biochem 2013; 72: 1-20

[49] Murashige T, Skoog F. A revised medium for rapid growth and bioassay with tobacco tissue cultures. Physiol Plant 1962; 15: 473-495

[50] Bhattacharyya P, Kumaria S, Diengdoh R, Tandon P. Genetic stability and phytochemical analysis of the in vitro regenerated plants of Dendrobium nobile Lindl., an endangered medicinal orchid. Metagene 2014; 2: 489-504

[51] Singleton VL, Rossi JA. Colorimetry of total phenolics with phosphomolybdic phosphotungstic acid reagents. Am J Enol Vitic 1965; 16: 144-158
[52] Chang CC, Yang MH, Wen HM, Chern JC. Estimation of total flavonoid content in propolis by 2 complementary colorimetric methods. J Food Drug Anal 2002; 10: 178-182

[53] Tambe VD, Bhambar RS.. Estimation of total phenol, tannin, alkaloid and flavonoid in Hibiscus tiliaceus Linn. wood extracts. J Pharmacogn Phytochem 2014; 2: 41-47

[54] Sreevidya N, Mehrotra S.. Spectrophotometric method for estimation of alkaloids precipitable with Dragendorf's reagent in plant materials. J AOAC Int 2003; 86: 1124-1127

[55] Kittipongpatana N, Porter JR, Hock RS.. An improved high performance liquid chromatographic method for the quantification of solasodine. Phytochem Analysis 1999; 10: 26-31 